Article

\title{
The Rights of Refugee Children and the UN Convention on the Rights of the Child
}

\author{
Jeanette A. Lawrence ${ }^{1,2, *}$, Agnes E. Dodds ${ }^{2,3}$, Ida Kaplan ${ }^{2}$ and Maria M. Tucci ${ }^{2}$ \\ 1 Melbourne School of Psychological Sciences, The University of Melbourne, Melbourne VIC 3010, Australia \\ 2 Victorian Foundation for the Survivors of Torture, Melbourne VIC 3122, Australia \\ 3 Melbourne Medical School, The University of Melbourne, Melbourne VIC 3010, Australia \\ * Correspondence: lawrence@unimelb.edu.au; Tel.: +61-4-1918-1624
}

Received: 13 June 2019; Accepted: 26 August 2019; Published: 31 August 2019

check for updates

\begin{abstract}
Refugee children are identified as rights-bearers by the United Nations Convention on the Rights of the Child (CRC), but their rights are not uniformly honored in the policies and practices of contemporary states. How the CRC's safeguards for refugee children's rights are honored depends partly on what it means to be 'a refugee child' and partly on how the claims of refugee children's rights are recognized, respected, and implemented in international and national legal and bureaucratic systems. We examine the CRC's affirmation of the rights of the child and analyze the CRC's articles in relation to the rights related to the life circumstances of refugee children and state responsibilities. Following an analysis of resistance to the CRC's mandates by contemporary states, we relate refugee children's rights to their refugee and developmental experiences and argue for repositioning refugee children into the center of protection dialogue and practice, internationally and nationally.
\end{abstract}

Keywords: refugee children; children's rights; children's agency; UN Convention on the Rights of the Child; developmental trajectories; refugee trajectories

\section{Introduction and Approach}

Millions of children continue to arrive at contemporary state borders seeking entry and protection. Many are turned away, and many others are treated as invisible or with suspicion as false or overwhelming petitioners. For the sake of these children and for the good of all humanity, there is a pressing need to reposition refugee children in international and national discourse on protection and rights. The United Nations Convention on the Rights of the Child (CRC; UN General Assembly 1989) clearly identifies refugee children ${ }^{1}$ as rights-bearers, but what are their rights, and how do contemporary international and national communities define and implement their rights? How well the CRC's safeguards of refugee children's rights are implemented depends partly on what it means to be 'a refugee child', and partly on how the rights-bearing status of refugee children is recognized, respected, and implemented in state immigration and legal systems. We argue that the CRC's rights-based guidelines are more appropriate for the protection of refugee children than welfare-based approaches and demonstrate how a rights-based approach fits analyses of refugee children's negotiations of their intertwining developmental and refugee trajectories over time in the sociocultural context. The CRC's right-based approach gives special recognition to refugee children as children with special needs. We analyze the CRC's articles in terms of their application to the needs and rights of refugee children. In contravention of the CRC's rights-based position on refugee children and responding to what they

1 Throughout this paper, we use the term 'refugee' in the general sense of any person seeking refuge outside their own country including asylum seekers. 
interpret as a current refugee crisis and populist politics, contemporary states favor national well-being and border security over the well-being of refugee children. We examine evidence that states have worked to relegate refugee children to the margins of protection discourse and to the margins of society. There are persistent tendencies to either overlook refugee children as invisible or to deny that they are children or refugees. We argue for a radical repositioning of refugee children into the center of the protection dialogue and into the center of state policy and practice. Only such a central position will give refugee children the due respect that is responsive to the intermingling of their refugee and developmental experiences and support their rights to develop fully in the present and future as envisaged in the CRC Preamble. ${ }^{2}$

\section{Identifying a Refugee Child}

The concepts of 'child' and 'refugee' are not consistently defined across disciplines, although both concepts are critical structural markers for positioning this doubly vulnerable group as children distinct from adults and refugees distinct from citizens. How refugee children's rights are recognized and enacted in legal and immigration systems is largely dependent on how refugee children are defined as being children and refugees.

\subsection{A Child}

There is no generic or typical child. Children differ from each other in many ways, including the defining characteristic of being a child distinct from an adult. The adult/child distinction may seem simple — children and adults are distinguished by age, where age is a rough marker of different periods of the life cycle. The simplicity of this distinction, however, is deceptive. Age-lines and the boundaries of life periods are moveable and vary within and across individuals in relation to personal experience and the sociocultural context. Each child is bodily embedded in a specific historical and cultural time and place that give her age meaning. Consider, for instance, a girl who is 12 years of age in the early 19th, 20th, or 21st century. Not only does the same age signify differences in what her life would be in her historical context, for instance, in what she is and does in a typical day, but it also has significance for the rest of her life and what she may hope to become. Her aspirations and expectations are constrained and enabled by her 12-year-old experiences of her sociocultural context, for instance, in open and closed educational and career pathways. Yet, as long as she is less than 18 years of age, she is a child according to the CRC, whose Preamble also recognizes that, as a child, she needs 'special safeguards and care'. Such special safeguards must be interpreted contextually for a child in her historical, temporal, and spatial embeddedness in her interactions with her specific sociocultural environment and in relation to her developmental experiences. If this girl is a refugee, then her refugee experiences must also be given appropriate interpretation in relation to her childhood experiences and circumstances.

Analyses of childhood as a life period distinct from adulthood have centered on whether children are theorized primarily as 'being' persons situated and active in the present or primarily as 'becoming' persons evolving into adults. Resolution of the dichotomy involves more than accepting present and future activities as important aspects of a child's life; it requires understanding how a child's present being at a particular period or point in time is inextricably intertwined with the developmental processes by which s/he is becoming over the whole of a lifetime. In addition, both present being and lifetime becoming are intertwined with a child's past—-the 'been' dimension that Hanson (2017) recently added to the picture. In emphasizing the significance of a child's past, Hanson appropriately pointed to non-linear unfolding and revisiting of each child's life experiences and interpretations. Although been, being, and becoming happenings are located differently in chronological time, in the

2 CRC Preamble: ' . . the child, for the full and harmonious development of his or her personality, should grow up in a family environment, in an atmosphere of happiness, love and understanding.' (UN General Assembly 1989). 
totality of a person's life experience, they move in and out of consciousness and make sense of the old and new and not-yet-experienced for that person. Past events and relationships resurface in the present, for example, in how past experiences of abuse or trauma are reiterated in refugee children's current unpleasant happenings (Kronick et al. 2018). Children project past and present events into their imagined future and color expected coming events with valences from previously or presently experienced happenings (Wang and Koh 2015). Experiences over time merge so that what children have experienced in their previous individualized and collective contexts affects how they engage with their current context and how they will encounter others in the future.

Being embedded in family and cultural contexts means that children are born with sets of ready-made and negotiable cultural and familial meanings held out to them to embrace as their own (Goodnow and Lawrence 2015). However, their sociocultural embeddedness does not mean that children are passive objects at the whim of environmental forces. They are reflective agents primed to make choices and act on personal meanings (James 2009; O'Higgins 2012). In their being, they 'coact' reciprocally with other parts of the sociocultural environment (Gottlieb and Halpern 2002; Overton 2015), initiating and responding to present events and relationships. In their becoming, they coact with others as they search out and confront future obstacles and opportunities.

Reciprocal engagement in those interactions brings about developmental changes in the children themselves and also in other persons and social structures in a child's environment (Kuczynski and Mol 2015; Lawrence and Dodds 2016; Overton 2015; Valsiner 2014). A child's becoming and maturing is intertwined with the nature of her individual and collective past and her present adaptive interacting with environmental constraints. The been, being, and becoming concepts thus work as a frame for identifying individual children as human persons whose past, present, and future developmental experiences and contextualized activities distinguish them from adults who are also in the process of developmental change. Each child, then, should be treated as an individual young person who is not an adult and who is embedded in a sociocultural time and place, similar in some ways to other persons and different from others by virtue of age, culture, race, gender, and an evolving personal developmental trajectory. From the perspective of children's experiences of been, being, and becoming, their rights and claims cannot be appropriately specified without reference to the living context and circumstances in which their rights are expressed.

The adult/child distinction promotes tensions that impact the ascription of rights to children. One tension occurs naturally in the underlying dynamics of children's relations with adults. Throughout childhood, human offspring vie for autonomy and independence from their parents at the same time that they seek nurturance and dependence. The tension drives systemic change in both the child and the adult and in their relationship, for example, in how parents adjust their parenting styles to children's overt and covert manipulations of their interactions and in the process develop new styles of interacting (Parkin and Kuczynski 2012). The rights of children may also undergo adjustment along with the changing dynamics and require recalibration.

Other structural tensions arising from the adult/child distinction have consequences for how states acknowledge children's rights. Policymakers may dismiss children's agency and treat them as parents' baggage, invisible or non-existent with respect to rights. Alternatively, recognizing that children do have special rights to protection, a different tension involves excluding from the definition of a child any asylum seeker whose age can be doubted (Bhabha 2001; Doná and Veale 2011; Ehntholt et al. 2018). Both these dismissive positions overlook the evidence that childhood and adulthood are different ways of being human but that the distinction is not always tightly defined or identified. Specialized rights normatively related to age are linked to the different social roles filled by children and adults that lose some of their distinctiveness when people are living in chaotic circumstances, for example, when a child needs to take on parenting responsibilities (Victorian Foundation for the Survivors of Torture VFST). 


\subsection{A Refugee}

A refugee is a person on the move whose movements are grounded in well-founded fear of persecution in their own country according to the UN Convention Relating to the Status of Refugees (UN General Assembly 1951). Refugees can be identified in terms of their status in international and national law or in terms of their embodied, existential experiences. Although the Convention's definition is usually followed (Pobjoy 2017), it can change with the interests of the defining party, according to Worster (2012), being broadened when the dominant interests are global and human-centered and narrowed when interests are domestic and bureaucratic. Definitions may also in change in public discourse with crisis events and their representation in the media. Goodman et al. (2017) revealed that descriptions of the same kinds of refugees change back and forth between suffering refugees in genuine need of support and threatening migrants to be controlled and kept out of Europe. A favorable categorization, for instance, following photographs of a drowned child changed back to unfavorable following the Paris terrorist attack of 2015.

People's legal migration status and visa conditions largely determine their quality of life and how refugee rights are enacted in domestic jurisdictions. Legal status is established as an invited refugee according to UNHCR global resettlement strategies, as an uninvited asylum seeker who arrives under acceptable arrangements, or as an uninvited asylum seeker arriving by arrangements considered 'irregular' or 'illegal' (Crock 2013; Mousin 2019). Receiving states have different ways of treating uninvited asylum seekers, including in a growing number of countries practicing routine detention of families and children (Silverman and Lewis 2017).

In people's lived experiences, a generic, representative refugee is no easier to find than a generic child. All refugee children and adults are bodily engaged in sets of events and relationships that, in temporal sequences, constitute the flight, transitions, temporary sanctuaries, and durable resettlement of their individualized refugee trajectories. Dobson (2004, p. 12) coined the term 'refugeeness' to capture these various sequential experiences and used it to describe the totality of various aspects of seeking protection in a state other than one's homeland.

\subsection{A Refugee Child}

The 'child' and 'refugee' labels together identify a minority category: 'refugee child' with a special basis for protection. Although the 1951 Convention does not explicitly mention children, the CRC Preamble identifies being a child as warranting special 'safeguards', 'care', and 'legal protection'. Article 22 makes further stipulations related refugee children, who are to be treated similar to any other citizen child. According to Pobjoy (2017, p. 21), Article 22 is 'the only provision in any human rights treaty that deals expressly with the situation of refugee children and children seeking refugee status'. That it was included in the face of disagreement by some states wanting to restrict rights to citizen children makes this article a strong international rights-based approach to refugee children.

Being a child has a certain precedence due to the developmental needs and vulnerabilities mentioned in the CRC Preamble (e.g., McAdam 2006; Smyth 2019). Pobjoy (2017), however, made a finer point that less is gained by trying to decide which concept-child or refugee-is primary than by recognizing the layers of interconnections across a child's developmental and refugee experiences and the ways in which their interconnectedness impacts a refugee child's present well-being and long-term future: 'It is important that protection is tailored to respond both to the difficulties associated with refugeehood and the distinct needs and vulnerabilities of childhood' (Pobjoy 2017, p. 15). This conjunction of the ordinary and the extraordinary resonates with relational accounts of the dynamics of a developing child's interactions with people and institutions in her specific sociocultural environment (Kuczynski and Mol 2015; Lawrence and Dodds 2016; Overton 2015).

A child cannot step away from the refugee-related experiences that may be simultaneously traumatizing and liberating (Barber 2014; Veronese et al. 2017). Neither can a child step away from the physical, cognitive, and behavioral changes $\mathrm{s} / \mathrm{he}$ is undergoing as a developing person, with unattended developmental experiences likely to reappear in later life problems and diseases 
(Shonkoff and Garner 2012). Children's individual experiences along their refugee trajectory are intertwined with the experiences of their developmental trajectory, with possible crossover effects of connections for children of different ages. Circumstances that have accumulated in one child's experiences may not be as relevant for another child who is at a similar phase in her own refugee trajectory but who is younger or older and attending to different developmental experiences and tasks at that time. Where a lack of resources may impede a six-year-old's ability to play, it may prompt a 16-year-old's exploration of independence in looking for peer group rather than family activities.

Negotiations of normative tasks in exceptional circumstances may change children's ordinary activities into extraordinary accomplishments and lead to the development of unexpected skills (Guyot 2007). Lucić (2016), for example, discovered how children took things into their own hands during the siege of Sarajevo. They efficiently managed the mix of the normal, everyday activity of walking to school with the exceptional skills they needed to dodge artillery in the streets. Negotiating treks across Africa when escaping war and slavery in the Sudan has also been the scene of children's ingenious adaptations to dangerous situations in preserving life for themselves and others (Luster et al. 2008). Children usually adjust to a new mainstream society faster than their parents, allowing them to take up novel roles as their parents' 'cultural bridges' (Goodnow and Lawrence 2015).

The appreciation of refugee children's simultaneous navigations through ordinary developmental and extraordinary refugee trajectories promotes a better-informed, child-centered perspective on international and national arrangements for protecting refugee children. UN High Commissioner for Refugees (UNHCR) guidelines identify how life experiences may adversely impact the sequenced normative experiences of developmental change that each child must continue to manage whatever else is happening. ${ }^{3}$ The normative/exceptional link underlines the significance of the scope and depth of the CRC's articulation of the rights of refugee children. That interconnected mix of childhood and refugeehood experiences is further complicated by the realization that what people treat as developmentally normative varies across cultural groups. Activities seen as violating children's rights in one cultural context may be accepted as culturally appropriate in another, for example, child marriage, care of ailing parents or young siblings, and involvement in family labor (Reynolds et al. 2006). Attending to children's whole of life (been, being, and becoming) experiences requires that analyses of refugee children's rights be grounded in their living situations (Liebel 2012) and their engagement with the sociocultural environment. Normative is variable, as is refugeeness, and refugee children do not come in one size or shape. Consequently, particular rights are likely to be more relevant in some situations and points of time in a child's individual refugee trajectory. For instance, a child is likely to need survival protection when engulfed in the violence of war and displacement, making the CRC's Article 6 'inherent right to life' clause relevant. When a child is resettling in a safe country, however, that may not be a dominant right, and the protection of a child's individual identity as specified in Article 8 may be more pertinent.

In summary, refugee children's lives cannot be understood without referring to their life circumstances, to how they interact with the environment, and to the personal meanings by which they frame their interactions across time and place. Refugee children are normal children living through the ordinary developmental experiences of childhood and also living through the extraordinary experiences of refugeeness (Derluyn and Vervliet 2012; Dobson 2004). Refugee children must negotiate their way through environmental circumstances that sometimes coalesce to support their development and well-being and sometimes clash and impede it. They are individual agents who interpret events, make choices, and initiate and respond to the activities of other people and social institutions (Kuczynski and Mol 2015). Refugee children are not well served by being sensationalized or pathologized, especially when these concepts become excuses for the normalization of distancing

3 Children are developing. They grow in developmental sequences, like a tower of bricks, each layer depending on the one below it. Serious delays interrupting these sequences can severely disrupt development UN High Commissioner for Refugees (UNHCR, p. 1). Refugee Children: Guidelines on Protection and Care. 
and exclusion. Intertwining refugee and developmental experiences do not turn a refugee child into an exotic exhibit, although media presentations of drowned or starving children may support that impression. It is appropriate to ask about the rights belonging to refugee children and whether they are entitled to make claims on the international community and sovereign states or whether they must forever be 'alien others' (Epps and Furman 2016) or objects of charity and benevolence.

\section{Refugee Children as Rights-Bearers or Welfare-Recipients}

The CRC proceeds from the premise that children are rights-bearers and assumes international agreement. That premise, however, is not universally endorsed by scholars. One contrary position by Hopman (2016) exemplifies proposals that children do not qualify as persons with rights at all. Another by Ferguson (2013) prefers a welfare-based approach over a right-based approach.

\subsection{Rights or Legal Privileges?}

Hopman (2016) questions whether children have rights at all-keeping alive a long-term philosophical debate and arguing from the Enlightenment positions of Kant and Rousseau, which state that children do not qualify as rational, free, social human persons, that is, adults who are able to make free choices. As pre-moral, pre-social, incompletely developed future adults, children cannot have rights. Instead, autonomous adults choose to give 'legal privileges to all children on an international legal level' (Hopman 2016, p. 284). The adult legal order is obligated to protect children, but that obligation does not carry the sense of rights that children may claim. Adults initiate children's privileges and enshrine them in social conventions that give them legal status as privileges rather than entitlements. Provisions for children are incorporated into adult legal systems, but because of their immaturity as non-adults, children themselves are not capable of being part of the legal discourse. This is a long way from a rights-bearer model of childhood.

Clearly, the legal systems that identify and arbitrate claims for children's rights are essentially adult organizations. That is why some of the proponents of children's rights have argued for children's greater participation and voice in those systems (e.g., James 2009; Prout 2011) and a leveling of their adult/child power imbalances (Federle 2017). The bureaucratic organization of the system, however, is not sufficient reason for denying children a proper legal basis for claiming the rights that the system upholds. Hopman's argument is deeply grounded in the insufficiency of children as fully rational persons, following her Kantian theory. Her question about children's human status is rhetorical, and her position leaves refugee children and all children as non-entitled petitioners whom adults and states may fail in dispensing benevolence. Her position leaves disenfranchised and dispossessed children without legal avenues for complaints or redress.

\subsection{Rights or Welfare?}

Ferguson (2013) proposed another alternative to a children's rights model, unfavorably comparing its relative merits to those of a welfare model and relying on outcomes as her ultimate test. In Ferguson's scheme, the expressive, procedural, and substantive reasons for a child-centered rights model fail because of her 'better-outcomes' criterion that lead her to conclude that neither fundamental human rights nor specific children's rights models adequately protect children or enhance their status in legal disputes.

However, Ferguson's position undersells the expressive 'signaling' significance of rights, although she acknowledged that a rights-based approach addresses the dignity of human persons. She misses the major point that dignity and worth reside in the person being recognized and respected and not in the person doing the respecting (Dickert 2010; Lawrence et al. 2015). Dillon (1992), by her philosophy of 'care respect', noted how protecting people is a special way of giving them respect that addresses their distinctiveness as well as their commonality. Ferguson's benevolence is different and comes from the character and intentions of the benevolent person. It is not called out as an entitlement or due. 
Missing that fine point of the origins of public signaling of children's rights, Ferguson proceeded to dismiss the expressive, procedural signaling value of a rights-based model, because she judged that it does not produce a better outcome than benevolence. In the public domain, however, neither expressiveness nor procedural justice are subsumed by outcomes. Children and adults have demonstrated appreciation of the processes involved in decision-making irrespective of the outcomes achieved when the procedures followed were seen as fair (Tyler 2006). Ultimately, although Ferguson does not deny children's rights, she argues that they neither adequately protect children nor enhance their status in legal disputes. Children's rights, in Ferguson's account, could not trump welfare. Similar to Hopman but from a different angle, Ferguson saw legal systems as dependent on adult benevolence rather than child rights and entitlement.

\subsection{Rights-Bearers}

In contrast with these welfare-oriented positions, a rights-based approach to the protection of children is a foundational and continuing feature of international law endorsed by the international community through the UN (UN High Commissioner for Refugees UNHCR) and articulated in the CRC The CRC articles authoritatively and unequivocally lay out the appropriate rights for setting up and monitoring national systems of children's rights. The Preamble assumes children have the rights of human persons and only addresses the rights of adults where they affect children's lives. The special case for children's rights rests on children's needs and entitlement to care that the Preamble grounds in development and family life and in the 'exceptionally difficult conditions' that warrant 'special consideration' for some children. In prohibiting torture or cruel imprisonment of a child, Article 37(c) further asserts the status of children as human persons who are entitled to dignity and respect, with an accompanying note on their age-related needs: 'Every child deprived of liberty shall be treated with humanity and respect for the inherent dignity of the human person, and in a manner which takes into account the needs of persons of his or her age'.

All children are entitled to the respect of being valued as human persons regardless of age, race, or social status (Dickert 2010). Within the scope of that umbrella of universal respect, children are also due a further level of respect that belongs to persons who are due the protective respect that Dillon (1992) calls 'care respect'. Children are entitled to protection, because they are liable to harm, and care respect draws attention to the particular concrete situations where their dignity may be violated. It indicates the rights that instantiate dignity and respect for persons in such at-risk circumstances (Lawrence et al. 2013, 2015). Freeman (2007) appropriately tied children's rights to respect, because they are the means for expressing and contextualizing respect for the respected ones; 'Rights are important because they recognise the respect their bearers are entitled to. To accord rights is to respect dignity: to deny rights is to cast doubt on humanity and integrity.' (Freeman 2007, p. 7). Rights, for instance, balance the interests of the powerful and the powerless (Federle 2017) and specify the details by which respect and dignity are worked out in changed roles and relationships. People's life circumstances vary, and the rights for preserving respect for children may differ across situations. A set of rights is required to apply the respect principle comprehensively, and the scope and details of the CRC articles fulfill that unique function as a normative rights-based framework for children's protection throughout childhood and in different national territories. The scope and details are especially applicable to the protection of refugee children.

\section{The CRC and the Rights of Refugee Children}

\subsection{The CRC's Provisions}

Primary among many CRC provisions for refugee children is their mandated inclusion and special protection. As Article 22 singles out refugee children as due special treatment, so does Article 23 for children with disabilities, thus putting two groups of disadvantaged children on equal footing with all others. That inclusive status is particularly valuable for children whose refugeeness may be used to 
treat them as 'alien others' to be excluded from domestic recognition and protection or to discriminate among them as more or less deserving. Derluyn (2018), for instance, reported how Belgium and several other countries have reorganized unaccompanied minors into two categories. One inclusive category of 'vulnerable unaccompanied minors' includes children under 14 years of age, those with psychological or medical problems, or girls. The rest are classified as 'not vulnerable unaccompanied minors' and are given lower levels of service and care. Derluyn (2018) appropriately interpreted this categorization system as moving from a basic rights focus to one of charity and generosity exercised as the state's benevolence. In that benevolence, refugee children who are assumed to be less vulnerable and consequently less deserving have fewer rights to care. This practice illustrates the practical outcomes of failing to acknowledge the inherent respect and dignity due to all refugee children and of grounding provisions of care in state benevolence and welfare rather than in rights.

Claimants of rights assert their entitlement, engaging in a public act and demanding a public outcome (Eekelaar 2002). A state and its institutions accept the responsibility to give such a claim serious attention and a decision. Including all refugee children among those who have the right to claim their rights is the basis for securing their dignity and entitlement in international and national legal systems. This fundamental social recognition directly opposes 'alien other' distancing or the subcategorization of some refugee children (Epps and Furman 2016). Modern states do not have the prerogative of distancing and dismissing refugee children from their legal and administrative provisions. While refugee children may not be well situated to make public claims of their rights in national immigration and legal systems, states are bound by their agreements as well as procedural justice to provide the legal and social support needed to assist children's progress through their systems (Crock 2013; Hanna 2019; O'Higgins 2012). Fresh moves to understand and employ children's natural agentic powers would sharpen and refocus attention on children's participation in social institutions (Tisdall 2017).

\subsection{The CRC Rights Belonging to Refugee Children}

The CRC's articles comprehensively detail the rights of all children to 'full and harmonious development' (Preamble). These details pertain to refugee children in at least five areas where the rights of refugee children gain particular relevance and meaning in relation to the intertwining of their refugee and developmental experiences. Refugee children have rights to the following: personal life and development; normal family life; health and well-being; safety and protection; and participation in the community. Ultimately, wherever international and national systems may process a refugee child's claims to rights, a primary consideration will be that child's best interests (Article 3) ${ }^{4}$.

\subsubsection{Rights to a Personal Life, Survival, and Development}

At the beginning of life, every child has the right to be registered and to have a name, an identity, and a nationality (7). Articles 16, 37, 39, and 40 identify each child as an individualized person who is due dignity, honor, respect, and self-respect. States are to ensure as much as possible refugee children's survival and development (6); preserve their identity, beliefs $(8,14)$, and dignity $(39)$; and direct education to their development and civic preparation $(27,29)$. Article 3 has special significance for refugee children, specifying the 'child's best interests' principle as 'a primary consideration' in all actions concerning them. These rights provide for more than simply surviving. They anchor refugee children's being and becoming to identifiable, individualized 'been' markers with continuity over time and situations.

4 In this section, for clarity, we use square brackets to reference individual CRC articles. 


\subsubsection{Rights to a Normal Family Life}

Refugee children have the right to be cared for by their parents in families free of arbitrary or unlawful interference $(7,16)$. Parents have the primary responsibility to secure 'conditions of living necessary for the child's development' and best interests $(27,18)$. If parents separate, refugee children have rights to information, access and regular contact, and family reunification $(9,10)$. States should provide foster care or adoption with cultural continuity (20). Affirming the normality of child development in families, these articles lay down normative principles of family solidarity and state non-interference. They prohibit willful bureaucratic separation of families or hindrance of family reunification, invoking at each point on the refugee trajectory the child's best interests $(21,3)$.

\subsubsection{Rights to Health and Well-Being}

States have responsibilities to provide healthcare for children domestically and internationally and to work to diminish infant and child mortality and suffering (24). State provisions include primary healthcare and education and social security $(24,26)$-all within standards of living adequate for children's holistic development (27). Two health areas relevant to refugeeness cover 'traditional practices prejudicial to the health of children' (24) and the recovery of child victims (39).

Article 28 specifies that states provide free primary education as well as accessible secondary, vocational, and higher education; ensure school attendance and discipline consistent with the child's dignity; and promote international cooperation for 'the elimination of ignorance and illiteracy' (28). States should provide refugee children with age-relevant play and recreational, cultural, and artistic activities (31) and regulation of any age-appropriate and non-exploitative work (32). The variability in indicators of high to low levels of well-being among children receiving trauma-related services points to the need for multiple forms of healthcare and intervention that draw on children's individual needs and coping strategies (Lawrence et al. 2019a; Watters 2012).

\subsubsection{Rights to Safety and Protection}

States are charged with protecting refugee children from all forms of discrimination (2); violence, injury, abuse, neglect, and exploitation (19); sexual exploitation and abuse, prostitution, or pornography (34); illicit transfer overseas (11); and being sold or trafficked (35). Regulation of children's conscription into armed conflict—an area touching many refugee children's lives-differentiates children younger and older than 15 years of age and provides protection and care for civilian children affected by armed conflict (38). In legal contexts, states are to protect refugee children from being treated cruelly or inhumanely and being denied liberty arbitrarily (37) or proper legal processes (40). State provisions include the production of informative materials for children (17). A state cannot avoid the extent of its obligations to manage refugee children's protection in its own legal system and internationally.

\subsubsection{Rights to Participate in Community}

Refugee children have the right to express themselves and their religious beliefs and to join in peaceful assembly (12-15). They also have the right to have national and international access to information sources, especially any promoting their well-being (17).

\subsubsection{Illustrative Example}

Overall, states' extensive responsibilities to secure the rights of refugee children involve taking account of parents' rights, ensuring the legality and standards of their own provisions $(3,41)$, reporting to the public — children as well as adults—and reviewing and reporting to the CRC Committee (43-45).

Consider, for example, siblings whose family arrives at a transit camp. These children in different childhood periods (ages) will be attending to achieving different age-appropriate developmental tasks and skills and will have some different primary indicators of their 'maximum possible survival and development', as specified in CRC Article 6. An infant sibling will be acquiring a style of attachment 
with their parents, with more and less secure styles that reflect his current security, which is also a critical start to how he will engage in future social relations. The infant needs support for the preservation of family relations and contacts specified in Articles 18 and 19 and the right to the viable alternatives in Articles 20 and 21 if things go wrong.

An adolescent sibling will be attending to issues of identity development, handling the tensions between independence and dependence, and balancing cognitive maturity with immature recklessness in problem-solving. This sibling may also need extra protection from external pressures to be recruited into armed combat or work and the exploitation that those activities may introduce into family life as identified in Articles 35 and 38. Meanwhile, another sibling in middle childhood may be happily finding items of play in unexpected places with unexpected playmates or be bemoaning or welcoming the lack of schooling, depending on individual differences. The specific sociocultural environment not only exerts constraints on what each sibling can do but also enables novel activities. Siblings will exert their own agentic constraints onto the environment and take up the opportunities they or others initiate (Valsiner 2014). As Guyot (2007) showed, the strange circumstances of refugee camps are resource-depriving and traumatizing for some, but present others with opportunities to thrive. Children have demonstrated ingenuity, flexibility, and leadership that transform traditional family structures and sometimes the organization of the camp. Their perspectives are not tied to images of what life was like in the past; they pick up communication requirements faster than adults and welcome changes in redistributions of patriarchal power. Formal claims of children's rights in such complex circumstances may be preceded or diverted by individual children's enactment of their rights to attend to their developmental needs without waiting for formal procedures.

\section{State Responses to Refugee Children's Rights}

Despite almost universal commitment to the CRC, many states fall short in implementing these guidelines in domestic immigration and legal systems. Avowed humanitarian aspirations are severely tested by economic, political, and technical constraints for states managing refugee children under both invited and uninvited conditions. Transit states close to war zones are often overwhelmed by waves of needy people, and some (e.g., Lebanon, Turkey, Uganda) become settlement rather than transit countries for people unable or unwilling to travel further. Some transit countries have poor refugee policies and facilities (e.g., Macedonia, Serbia), and some resettlement states have already overstretched resources (e.g., Greece, Italy). Even wealthy countries are subjected to nationalistic perceptions of threat that pressure for normalized and routinized rejection of uninvited asylum seekers (Silverman and Lewis 2017). Rhetoric about a refugee crisis is boosted by threats of terrorism and nationalism, and signs of 'refugee tragedy fatigue' (Bauman 2016, p. 2) surface as ambivalence towards children labeled as 'irregular' or 'illegal' (Bhabha 2014).

Smyth (2019, p. 450) recently went further, identifying as 'active negation' the suppression of a children's rights agenda in favor of an immigration control agenda. The Australian government's intent certainly was negation in an incident in 2001 involving families trying to arrive by boat. Government officials used media-fueled sensationalism to gain public acceptance of alienating and distancing attitudes. Reports were widely published that asylum seekers threw their children into the sea so that they would be rescued by the Australian navy. Slattery (2003) analyzed media material of the event, reading as deliberate fabrication the government's staging of asylum seekers as 'other', ethically unworthy people, and the antithesis of ethically worthy Australians and their government. The children were sensationalized as pawns by which evil parents sought to manipulate the Australian authorities and the public. It was later found that parents had not thrown their children into the sea; the boat was sinking from under them. Crock (2013, p. 35) demonstrated how Australian policies and practices rested on a 'deterrence theory' that successive governments have used to justify the detention of existentially present children as a strategy for deterring putative children who would presumably arrive illegally by boat if this deterrence were not in place. 


\subsection{Collateral Damage: Not Normal Families}

The normalization of border protection is littered with possibilities of managing children as collateral damage when processing adults' claims and of denying that unaccompanied children are children or refugees. It is administratively convenient to position children as parents' appendages or as simply not present when immigration decisions or detention arrangements are being made. The Canadian migration system did not keep records or even count children placed in detention with their asylum seeker parents, and this neglectful recordkeeping has only recently been revised (Kronick and Rousseau 2015; Kronick et al. 2018). In Sweden, Lundberg and Lind (2017) found that immigration officials did not refer back to their notes and inefficiently but effectively overlooked useful information. Because these officials did not understand children's rights, they did not seek information about the children's specific experiences that was in the notes and would have strengthened the children's claims for asylum (e.g., being battered by teachers, arrested by police, or having witnessed the rape of one's mother).

Although detention and deportation practices are not prohibited by international law, a recent 2018 UNHCR news release stated that detention of refugee children 'always constitutes a rights violation' . This seems to go further than Article 37, which prohibits the 'unlawful' deprivation of children's liberty, unless Article 37's clause (a) is used to infer that all detention involves torture or cruelty ${ }^{6}$. According to Article 37 clause (b), lawful imprisonment must be 'a measure of last resort and for the shortest appropriate period of time'. Yet, Mousin (2019) reported how detention is used as a first resort in the United States (US) and results in sending refugee families to secure but substandard processing centers for longer than the US' mandatory 72-hour limit (Linton et al. 2017). Euphemistic labeling of those family detention centers as luxury accommodation cloaked the reality of their resemblance to jails (Antony 2019) and conditions exemplifying Article 37(a)'s prohibitions against inhumane and cruel incarceration of children.

There can be no doubt that detention does not provide refugee children with environments fit for normal family life. Whether children are detained with parents or left in the community separated from one or both of them, family life is effectively disrupted or destroyed. As sites of children's development, detention centers represent the kind of toxic environments (Shonkoff and Garner 2012) where children's interactions with adults promote cumulative trauma, stress, fear, and hopelessness (e.g., Coffey et al. 2010; Ehntholt et al. 2018; Hodes 2010). Psychiatrists and service providers have built an evidential base of children's adverse physical and emotional ill-health, developmental delays and adjustment difficulties, and long-term mental health problems (Kronick et al. 2018; Linton et al. 2017; von Werthern et al. 2018).

In an unusual study of children's perspectives on life in detention, Kronick et al. (2018) asked children aged from 3 to 13 who experienced detention in Canada to describe their worlds with sand play constructions and stories. Analyses revealed three themes in the children's perspectives on their environments: confinement and surveillance, loss of protection, and human violence. One 11-year-old girl created a sand play scene of detention that she said was 'like a prison', where her father was separated from the rest of the family and where men watched to stop them from fleeing. Her scenes and narratives changed from an originally hopeful view of Canada, where she related police figures to providing safety two weeks into detention. After a month, she created another scene and described general deterioration-'in future, everything gets worse' - and the police as ominous watchers (Kronick et al. 2018, p. 426). From a been, being, and becoming perspective, this child-oriented research provides indicators of refugee children's merging of past traumas with present traumatic events and projections of present hopelessness into the future. It also shows how the toxicity

5 UNHCR Press briefing notes on Egypt, the United States, and Ethiopia, 5 June 2018. Retrieved from: https://www.ohchr.org/ EN/NewsEvents/Pages/DisplayNews.aspx?NewsID=23174\&LangID=E.

6 CRC Article 37(a) 'No child shall be subjected to torture or other cruel, inhuman or degrading treatment or punishment.' 
of a detention environment can interfere with the 'full and harmonious development' to be protected in line with the CRC Preamble.

Henderson (Henderson 2014, p. 1174) proposed that there is a prima facie case for Australia to answer and that its onshore and offshore detention of child refugees constitutes a crime against humanity with respect to the severe deprivation of physical liberty. With little doubt that asylum seekers' lack of liberty and experiences of persecution violate international human rights law, Henderson, however, admitted that there is little prospect of a courtroom test. Domestic prosecution requires the consent of an Australian Attorney General, and there is no enforceable human rights mechanism in Australia. Internationally, the limited resources of the International Criminal Court combine with definitional and evidential obstacles to establishing national discrimination, persecution, and the grounds for targeting prosecution. Sometimes, exposure of political failure is able to trigger public pressure if not legal action, and public protests and petitions in 2019 have secured some medically related releases of detainees from offshore detention centers, despite government resistance.

Viable alternatives to detention proposed by the International Detention Coalition (2010) include open reception, accommodation centers, and release options. Silverman and Lewis (2017), for instance, reported how several countries, including Belgium and Japan, moved to open family facilities and monitoring committees. More careful screenings and assessments of children's immigration status would avoid routinizing detention, as would clearer interpretations of Article 37's 'shortest period of time'. The US' 72-hour limit is reasonable but is not routinely honored (Linton et al. 2017). Other countries, including Australia, do not have mandatory timeframes. It appears that modern states are determined to persist with detention arrangements for families with children, whether through conviction, convenience, or desperation. In light of the relative inability of researchers, practitioners, and advocates to dissuade governments from their fascination with locks and surveillance, there is urgent need of research evidence to assess the economic as well as human gains of shorter timeframes in detention and the use of alternatives.

\subsection{Unaccompanied Minors: Not Children or Not Refugees?}

Definitional problems are especially relevant to how states position unaccompanied children in assessment and care arrangements. Despite its developmental arbitrariness, the bureaucratic 18-year-old child/adult cutoff presents unaccompanied minors with some particular difficulties, including accusations of being 'imposter children' or 'bogus refugees' (Silverman 2016, p. 31), and either abrupt cessation of services or delayed family reunification until they are considered 'adult', depending on domestic legislation. It also has invited the normalization and routinization of faulty age measurement (from medical measurement to officials' cursory judgments; Crawley 2010; Ehntholt et al. 2018). Judgments of adult/child differences can be equally faulty. Bhabha (2001) reported how children arriving in the US after the 1994 Haitian military repressions encountered age-related discrimination. US officials believed that the traumatic events that these children reported having experienced could not believably come from children. Such things would not happen to children, and therefore, these must be adults. Many were forcibly repatriated. Hodes (2010) noted similar bureaucratic doubt in Europe about some unaccompanied children's claims to be younger than 18 years of age and entitled to greater support. Boys, especially those from Afghanistan are frequently unable to produce birth certificates, because births were not routinely recorded in their country. Their lack of documents is used to support the perception that they are threats and is used to justify deporting them from the United Kingdom (UK) (Silverman 2016).

In the UK, until 2005, officials were able to judge a child's age with a cursory look. Children reckoned to be older than 18 years by immigration officers were treated as adults for all immigration 
decisions including detention (Ehntholt et al. 2018). A 2019 UK Court of Appeal decision found that the Home Office assessment policy to determine the age of young asylum seekers was unlawful ${ }^{7}$.

\subsection{Resettlement Arrangements}

Upon acceptance as humanitarian refugees, children and their families can get on with the work of recovering from trauma, rebuilding their lives, and refocusing attention on the ordinary developmental tasks from which their extraordinary displacement and transition experiences had deflected much of their attention and energy. Within the best of resettlement arrangements, numbers of children still experience disruption of family life, accommodation, and education; bureaucratic obstacles to accessing health and social services; and social discrimination and exclusion from decision processes concerning their lives. Resettlement difficulties have their own manifestations and effects that, for some children, cumulatively build on presettlement traumatic experiences and, for others, are new, unanticipated obstacles, related, for example, to the location and provision of housing or schooling (e.g., Fazel et al. 2012; Hodes 2010; Montgomery 2011; Victorian Foundation for the Survivors of Torture VFST). In Quebec, for example, refugee children and young adults encountered structural obstacles throughout their negotiations with health and educational institutions (Buccitelli and Denov 2019). They found themselves dealing with conflicting norms, exclusion, discrimination, and racism, and the reality of their interactions with government systems did not match the welcoming rhetoric. The facilities of modern life were both fascinating and confusing for children and young people from Africa and Asia resettling in the US Midwest, for example, water running from a tap, buses, and libraries (Bettmann et al. 2017). These children found their greatest challenges in integration to be activities that involved language and cultural differences, especially in the prized making of friends. The ability to integrate while retaining a sense of one's own identity is a major protective factor in resettling successfully in wealthy countries (Fazel et al. 2012). Self-protection and self-expression are strong reciprocating motivations in children's negotiations of their needs and preferences. Provisions and services may be generous without being coordinated with individual children's needs and adaptive abilities, because of welfare-oriented approaches, cultural insensitivity, or failing to listen to individual children (Buccitelli and Denov 2019; Victorian Foundation for the Survivors of Torture VFST).

\subsection{Participation in Society}

People are natural participants, embedded in sociocultural environments and relationships throughout life. Children look for and engage in connections with people, although their styles of participating in talk and action may reflect past successful or flawed interactions with the same or other people and institutions. CRC Articles 12, 13, and 15 appropriately frame children's social participation in terms of their rights to form and express their views and beliefs about their lives. Refugee children's expressions may be constrained by the topic of their comments and by the risk suggested by their reading of aggressive or unsympathetic adults. In such circumstances, silence and withdrawal may be the most expressive communications powerless children can make (Ní Raghallaigh 2013). A rights framework carries communication forward beyond youthful expression to adult enabling and obligation to attend to the concerns in refugee children's expressions. Agentic children naturally negotiate and make claims, without first shedding the vulnerability of their past traumas ( $\mathrm{O}^{\prime}$ Higgins 2012), and adults are likely to be more enabling of children's participation when they are aware of the complexities of refugee trajectories. To be excluded from negotiations challenges the identity of a person who may have an uncertain hold on the right to participate. Dignity and respect are at stake, with social recognition of one's worth impacting on one's self-respect (Dillon 1992).

$7 \quad$ England and Wales Court of Appeal (Civil Division) Decisions. BF (Eritrea) v Secretary of State for the Home Department [2019] EWCA Civ 872; [2019] WLR (D) 300. 
Recognition of children's agency and potentialities has been implemented in several programs in Italy and other European countries that expressly address children's autonomy, choice, and genuine involvement in decisions about their lives and housing arrangements (Rania et al. 2018). Young people are often critical of the interactive styles of the professionals involved in their care (Buccitelli and Denov 2019; O'Higgins 2012; Valibhoy et al. 2017), so it is important for intervention programs to preserve and promote children's agency and dignity. Rania et al. (2018), for instance, reported how one program arranging accommodation for unaccompanied minors was careful to include information and routines that would support their autonomy and strengthen relationships in the community. Part of understanding the agency of refugee children is to establish interactive styles that explicitly acknowledge that their relations with professionals are coactive and are founded on the enactment of reciprocal respect. Trained community-located mentors can facilitate children's negotiations with bureaucracy at multiple levels (Rania et al. 2018).

In summary, as they acculturate to their new countries, many young refugees and immigrants bring unique insights to analyses and resolutions (Morantz et al. 2011; Watters 2012) and construct bicultural identities that embrace both host and original cultures (Goodnow and Lawrence 2015). As entitled contributors, refugee children have a stake in the dialogue that would not be theirs as welfare recipients. Realization of their entitlements, however, requires enabling and that requires due recognition of these children's commitments and abilities. As one young Chaldean woman told her non-supportive university teacher about her challenges, 'You don't know my story and how I got here' (Lawrence et al. 2019b). Informal support, but not her teachers' enabling, encouraged this refugee young woman to overcome present barriers to her future professional advancement.

\section{Engaging with Rights in Intertwining Developmental and Refugee Experiences}

Once refugee children are recognized as persons younger than adults with the right to survive and develop with dignity through the expected, normal experiences of childhood, it is possible to incorporate into that normative framework their extraordinary refugee experiences. How a given child's maturational and refugee experiences are intertwined in a particular time and place is likely to point to specific rights that can enhance the quality of that child's immediate being and future becoming in relation to the particulars of dislocation and loss s/he has been through. For instance, we found that two teenage girls who had been separated from their families for years were most interested in claiming the right to family reunification that in Australia belonged to them as unaccompanied child humanitarian refugees (Lawrence et al. 2016). They directed their own efforts and those of their case workers towards achieving that end. In contrast, a teenage boy who had been an asylum seeker and did not have that same entitlement concentrated his claims on securing entrance to his chosen school courses and subjects. He saw achieving his high educational aspirations as his best way to become successful and to be able to help his family.

\subsection{Engaging with Living Rights}

Children's understanding of their rights is part of their valuing of events and relationships and their place within their sociocultural environment. As they observe and assess their own and other people's relationships, they develop a sense of their entitlements and responsibilities along with other subjective perceptions of cultural norms and rules. According to Hanson and Nieuwenhuys (2013), children's rights are 'living rights' that are shaped in their everyday concerns rather than being defined and handed down by adult institutions. Children do not simply discover their rights by being exposed to official rights discourses. They 'become aware of their rights as they struggle with their families and communities to give meaning to their daily existence' (Hanson and Nieuwenhuys 2013, p. 4).

The point is well taken that children's rights are embedded in their life circumstances, but it is only part of children's valuing. Rights, like other meanings attached to children's relationships, are constructed in a cyclical process of noticing and negotiating activities in which the child is sometimes the instigator and sometimes the responder. However, children are not born into value-free sociocultural 
contexts. Most of their induction into daily social interactions comes with evaluative, normative tags. Most human relationships come with accompanying permissions and sanctions. For example, it is usually permitted for children to accept gifts from elders, but they are expected to reciprocate by giving thanks. The taking up and enactment of their rights-based entitlements are more dynamic and interactively constructed than Hanson and Nieuwenhuys (2013) suggest.

Children's understanding of norms and social rules is generated and refined in their ongoing interactions with the sociocultural world (Goodnow and Lawrence 2015). All people's constructions of meanings begin with the materials and norms belonging to culture and held out to them for their processing (Valsiner and Lawrence 1997; Valsiner 2014). From their early years, children are observers, interpreters, and actors who are busy decoding cultural norms, practices, and symbols in order to find out what is expected of them in their relations and what they may do to signal what they expect (Diesendruck and Markson 2011). They have norms and rights pointed out to them and also discover others serendipitously in interactions. Children are able to embrace or ignore adults' sensitizing suggestions (Kuczynski and Mol 2015). When they do take values and rights into their own thoughts and beliefs, children, as do adults, interpret and personalize the material and make it their own. What was previously social becomes personal.

New awareness of a right opens up new activities as the right is accessed and processed for claiming, for example, when children embrace situations in countries of resettlement that had not been available in their homeland, such as educational opportunities and gender equality (Goodnow and Lawrence 2015). New activities open up new causes for seeing that a right is involved, for example, when political upheaval and dislocation disrupt existing power structures and permit unprecedented openings for youthful leaders (Barber 2014; Guyot 2007).

\subsection{Claiming of Refugee Children's Rights}

It is a moot point whether children's living rights must be discovered in their struggles with life circumstances, as Hanson and Nieuwenhuys (2013) argue, or whether the personalizing and owning of rights may follow equally well from formal education and advocacy where rights talk is normal. Adolescent children of Somali refugees resettling in urban Australia troubled their parents by invoking their newfound rights to student or unemployment allowances that gave them some financial independence from their parents, and to their understanding, emotional independence. These Somali-Australian children also discovered that there are Australian laws prohibiting parents from beating their children. The parents complained to us that their children were threatening them with the police or the welfare department if they dared to discipline them physically as they would in Somalia. Bettmann et al. (2017) found similar bewilderment about US laws among parents from several African and Asian refugee communities. We presume that these children became aware of their rights at school through either formal or informal processes and realized they could make use of the novel information at home. The living aspect belongs to wielding their newfound rights in family interactions and not how they became aware of those rights.

An example of political action by school students illustrates children's taking up of rights to which they were sensitized and their follow-through with attempts to make public claims that provoked social controversy. Clark-Kazak (2010) reported an incident that occurred in Kyaka ll Camp in Uganda. In 2004, a small group of Congolese refugee students attempted to claim free high school education. After several rounds of discussion and the school's suggestion of part-payment or in-kind alternatives, about 20 Congolese students who refused to pay were excluded from school. Refugee students had been sensitized to the CRC articles on education rights by agents of an international non-government organization (NGO). The students refused to pay full or partial fees or in-kind work. They wrote letters to the UNHCR and the Ugandan government but received no response. They demonstrated at the school. A small group of 14 was arrested, beaten, held for three days, and then released without charge. They had hoped to explain their demonstration and make their claim in court. 
Clark-Kazak (2010) interviewed some of the demonstrators, other young people, Congolese and Ugandan community members, and officials as part of a larger study about the political roles of refugee young people. Many of her respondents referred to the school fees incident, which had become an important reference point in the socio-political landscape. Clark-Kazak (2010) found generational differences in the meanings people attached to the incident, with little differences in the telling of events. Young Congolese refugees interpreted events as evidence of hierarchical decision-making in the camp and obstacles to their participation. Those who had been involved in the demonstration were upset that they did not get a chance to speak in court. Adults from both Congolese refugee and local Ugandan communities were more concerned about the lack of supervision of the young demonstrators as rebellious, undisciplined, and causing trouble. Most adults condemned the demonstrators but also condemned the actions of camp authorities and interpreted the alleged human rights violations as power abuses.

There are several implications here for understanding the enabling and enactment of children's rights. As we have indicated throughout, the students' actions must be approached with attention to their situational embeddedness. First, Clark-Kazak noted that most of the demonstrators were living in peer-group accommodation at the time and that these living arrangements were quite different from normal Congolese family living arrangements with parental supervision. The young people's living circumstances, according to the Hanson and Nieuwenhuys (2013) analysis, were already conducive to children making their own life decisions. Second, into that situation, the NGO agents introduced CRC concepts of children's rights to education. Then, Clark-Kazak seems to suggest that the NGO agents had interpreted education rights to include free secondary education. The wording of Article 28(b) directs the state to 'make them [different forms of secondary education] available and accessible to every child, and take appropriate measures such as the introduction of free education and offering financial assistance in case of need'. Clause (a) only stipulates that primary education must be 'compulsory and available free to all'. The application of Article 22 also requires interpretation in relation to evidence that the fees were imposed on local Ugandan and refugee Congolese children, but Congolese children were asked to pay less and were offered alternative arrangements. How the rights initiative was generated was not revealed. We present this incident as an illustration of the cyclical relations between rights and experiences in relation to the power of individuals' interpretive meanings and the significance of a child's holistic interactive engagement with the sociocultural context. The cross-generational differences in perspectives are not surprising and show the convergence of refugee experiences with developmental trajectories for children and adults. The original protesting high school students and later young commentators were in an age of heightened cognitive ability but also heightened willingness to take social risks in the company of peers (Cauffman and Steinberg 2000). This does not imply that their political activities were immature or impetuous but, rather, that they were at a period of life when political activism and a public forum in which to make their protest was seen as possible.

Public acts of rights claiming are not easy for children who have suffered humiliation and discrimination and are seldom made by children in rights-violating contexts, according to Liebel (2012). At the least, if children are to embrace and make public claims of their rights, their rights must be comprehensible to them and actionable in relation to their personal priorities and safety. Snodgrass Snodgrass Godoy (1999), for instance, noted individual variability in the personal cost and danger incurred by street children who dared to claim their rights as victims of crime in Guatemala City. Some courageously tackled the protracted and risky processes of claiming their rights through the system. Others with little confidence in public procedures preferred to rely on their own methods of exacting reprisal and revenge. When rights are presented in the public domain, they regulate action and therefore are likely to be met with resistance by powerful people unwilling to surrender their power. Such resistance occurs at all levels of political and legal systems, making urgent and pressing the need to provide refugee children with appropriate legal safeguards and especially legal representation (Crock 2013; Hanna 2019). Federle (2017) questioned whether rights must inevitably run downhill from adults to children, but children's rights claiming is not always adult initiated. Dignity 
and respect are instantiated when rights are prominent in public discourse and when children are supported to step forward as claimants of their rights. Child-initiated global movements for climate awareness and gender equality are illustrative of the willingness of children to take political action when their rights are repositioned and enabled.

\section{Conclusions: Repositioning Refugee Children in the Protection Dialogue}

It should not be necessary to reposition refugee children in the protection dialogue. A central position has already been secured by the CRC and acknowledged by international agreement and treaties. Nevertheless, repositioning is required in the provision, protection, and participation offered by contemporary states, because they are not uniformly honoring the CRC-guaranteed rights of refugee children in domestic policies and practices. In light of the volume of people seeking refuge, the dialogue has shifted to favoring national well-being over the well-being of refugee children. At least domestically, refugee children need to be repositioned into the center of the protection dialogue and also into the center of national consciousness and action. Refugees who are children as well as other refugees are being consistently relegated to the margins of societal concern and action.

Repositioning is warranted. The respect that is due to all persons is augmented in the case of disadvantaged, at-risk children by protective, care respect for persons with special needs (Dickert 2010; Dillon 1992; Lawrence et al. 2015). To be left at the margin of protection concerns is the opposite of respect and dignity. It carries the sense of dehumanization that Esses et al. (2017) saw as the political response of many states to refugee children and also the sense of pathologizing that subsumes political realities to over-psychologizing, as identified by Doná and Veale (2011). Repositioning refugee children at the center avoids disrespect and its accompanying stripping away of refugee children's rights. It focuses attention away from threats and crises and directs action to advancing the respect that facilitates refugee children's self-respect.

A central position in the protection dialogue belongs to refugee children by right. Respect is instantiated and contextualized in the rights that the CRC guarantees for the total development of disadvantaged children. Conceptually, positioned in the center of the protection dialogue, refugee children cannot be framed as recipients of welfare offerings dispensed as discretional national benevolence, as we interpret the implications of Ferguson's (Ferguson 2013) position, or as the recipients of legal privilege in Hopman's (Hopman 2016) analysis. By repositioning refugee children into the center of the protection dialogue, we have expanded analyses of refugee children, their rights-bearing status, and state obligations.

Without falling back on traditional assumptions about the generic child or the generic refugee, it must be acknowledged that children are not as powerful as adults and that they are in need of protection, especially when they are forced into dislocation and migration by adult violence. Neither are children passive and inactive. They are constantly negotiating their personal being in their immediate sociocultural environments as well as their becoming as adult contributors. Children are observers of events and relations, whose insights and perspectives differ from those of adults. They do not need adults to recraft children's perspectives and beliefs in order to act upon them. As interpreting and negotiating agents who are liable to exploitation, refugee children, nevertheless, need protectors and enablers who assist them to claim their rights instead of treating them as lucky recipients of adult benevolence. A rights-based approach that instantiates respect functions to redress the adult/child power imbalance and to give refugee children opportunities to contribute to their communities and future generations.

Legally and politically, states are obliged to recognize and honor the entitlements of refugee children to call upon the provisions and services of their national institutions and representatives. Respecting the rights of refugee children means attending to their claims in public decision systems, providing appropriate procedural safeguards for the processing of those claims, and answering the claims with equitable distributions of power and resources. 
In this era of global displacement, there is little sense in ignoring the national as well as international costs of continuing waves of mass movements of children needing protection. Without significant intervention, the numbers of children fleeing from violence and dislocation are not likely to diminish or to relocate away from the poorest nations. There is good sense, however, in acknowledging refugee children as significant stakeholders in human destiny. As Antonio Guterres commented on the need for unprecedented humanitarian response: 'What is at stake is nothing less than the survival and well-being of a generation of innocents' (Redden 2013). For resettlement societies, the potential loss of a generation of productive contributors is also at stake. Humankind cannot afford to lose the potential of what refugee children have to offer socially and economically, in the future and also in the present. If current economic trends persist, these children are on course to become stable economic as well as social contributors to their new countries (Hugo 2014; Kerwin 2018). Repositioning refugee children away from the margins is vital for the well-being of the world as well as for the well-being of refugee children.

We have emphasized the importance of treating refugee children as normal children dealing with exceptional events and relationships. Their refugee experiences intertwine with their developmental experiences, and they encounter their rights in different ways. Refugee children are survivors, stakeholders, and ready to work and prosper. They have demonstrated personal resilience and commitments to bridging gaps in their elders' negotiations with local bureaucracies and communities (Goodnow and Lawrence 2015; Guyot 2007). Just as it is as inappropriate to pathologize refugee children's experiences, so it is inappropriate to deny their rights to claim the protection and support that will prompt their well-being and thriving. Thirty years on from the CRC, it is timely to engage again in the kind of coordinated discourse and action that led to the CRC's formulation and acceptance, with the caveat that, today, any repositioning of refugee children must involve them in the conversations. The international community should refocus on refugee children, not as costly intruders, but as rights-bearers and contributors, reconfiguring how they are recognized and respected throughout their refugee and developmental trajectories.

Author Contributions: (1) J.A.L.- - developmental psychologist with a research background in psychology, philosophy, and education; (2) A.E.D.- - medical educator and evaluator with a research background in refugee children; (3) I.K.- - clinical psychologist specializing in the provision of direct services to victims of torture and trauma and refugees; and (4) M.M.T.- who has a background in social work, law, and international development and provides trauma counseling and legal services and advocacy for asylum seekers and refugees. Each author has made substantial contributions to the conception and development of the work; its argument and analysis of relevant materials; and revisions. Each author has approved the submitted version and agrees to be personally accountable for her own contributions and for questions related to the accuracy or integrity of any part of the work. The original idea was developed by J.A.L. Then, each stage of the development of the argument was discussed in joint meetings. All the authors made substantial contributions to the final manuscript.

Funding: This research received no external funding. The research was funded by the Victorian Foundation for Survivors of Torture and the University of Melbourne.

Acknowledgments: We gratefully acknowledge the support of the University of Melbourne and the Victorian Foundation for Survivors of Torture.

Conflicts of Interest: The authors declare no conflicts of interest. The funding institutions had no role in the design, analyses, or interpretations; in the writing of the manuscript; or in the decision to publish the results.

\section{References}

Antony, Mary Grace. 2019. How Moral Disengagement Facilitates the Detention of Refugee Children and Families. Journal of Ethnic and Migration Studies 45: 770-86. [CrossRef]

Barber, Brian K. 2014. Research on Youth and Political Conflict: Where is the Politics? Where Are the Youth? Child Development Perspectives 8: 125-30. [CrossRef]

Bauman, Zygmunt. 2016. Strangers at Our Door. Cambridge: Polity.

Bettmann, Joanna E., Mary Jane Taylor, Elizabeth Gamarra, Rachel L. Wright, and Mai Trinh. 2017. Resettlement Experiences of Children Who Entered the United States as Refugees. Social Development Issues 39: 1-18. 
Bhabha, Jacqueline. 2001. Minors or Aliens? Inconsistent State Intervention and Separated Child Asylum-Seekers. European Journal of Migration and Law 3: 283-314. [CrossRef]

Bhabha, Jacqueline. 2014. Child Migration and Human Rights in a Global Age. Princeton: Princeton University Press. Buccitelli, Andie (Saša), and Myriam Denov. 2019. Addressing Marginality and Exclusion: The Resettlement Experiences of War-Affected Young People in Quebec, Canada. Children 6: 18. [CrossRef] [PubMed]

Cauffman, Elizabeth, and Laurence Steinberg. 2000. (Im)Maturity of Judgment in Adolescence: Why Adolescents May Be Less Culpable Than Adults. Behavioral Sciences and the Law 18: 741-60. [CrossRef]

Clark-Kazak, Christina. 2010. The Politics of Protection: Aid, Human Rights Discourse, and Power Relations in Kyaka II Settlement, Uganda. Disasters 34: 55-70. [CrossRef]

Coffey, Guy J., Ida Kaplan, Robyn C. Sampson, and Maria M. Tucci. 2010. The Meaning and Mental Health Consequences of Long-term Immigration Detention for People Seeking Asylum. Social Science and Medicine 70: 2070-79. [CrossRef]

Crawley, Heaven. 2010. 'No one Gives You a Chance to Say What You are Thinking': Finding Space for Children's Agency in the UK Asylum System. Area 42: 162-69. [CrossRef]

Crock, Mary E. 2013. Of Relative Rights and Putative Children: Rethinking the Critical Framework for the Protection of Refugee Children and Youth. Australian International Law Journal 20: 33-54.

Derluyn, Ilse, and Marianne Vervliet. 2012. The Well-being of Unaccompanied Refugee Minors. In Health Inequalities and Risk Factors among Migrants and Ethnic Minorities. COST Series on Health and Diversity. Edited by David Ingleby, Allan Krasnik, Vincent Lorant and Oliver Razum. Antwerp-Apeldoorn: Garant Publishers, vol. 1, pp. 95-109.

Derluyn, Ilse. 2018. A Critical Analysis of the Creation of Separated Care Structures for Unaccompanied Refugee Minors. Children and Youth Services Review 92: 22-29. [CrossRef]

Dickert, Neal W. 2010. Re-Examining Respect for Human Research Participants. Kennedy Institute of Ethics Journal 19: 311-38. [CrossRef]

Diesendruck, Gil, and Lori Markson. 2011. Children's Assumption of the Conventionality of Culture. Child Development Perspectives 5: 189-95. [CrossRef]

Dillon, Robin S. 1992. Respect and Care: Toward Moral Integration. Canadian Journal of Philosophy 22: 105-32. [CrossRef]

Dobson, Stephen. 2004. Cultures of Exile and the Experience of Refugeeness. Bern: Peter Lang.

Doná, Giorgia, and Angela Veale. 2011. Divergent Discourses, Children and Forced Migration. Journal of Ethnic and Migration Studies 37: 1273-89. [CrossRef]

Eekelaar, John. 2002. Personal Rights and Human Rights. Human Rights Law Review 2: 181-97. [CrossRef]

Ehntholt, Kimberly A., David Trickey, Jean H. Hendriks, Hannah Chambers, Mark Scott, and William Yule. 2018. Mental Health of Unaccompanied Asylum-Seeking Adolescents Previously Held in British Detention Centres. Clinical Child Psychology and Psychiatry 23: 238-57. [CrossRef]

Epps, Douglas, and Rich Furman. 2016. The 'Alien Other': A Culture of Dehumanizing Immigrants in The United States. Social Work and Society 14: 1-22. Available online: hppt://nbn-resolving.de/urn:nbn:de:hbz: 464-sws-1088 (accessed on 3 June 2019).

Esses, Victoria M., Leah K. Hamilton, and Danielle Gaucher. 2017. The Global Refugee Crisis: Empirical Evidence and Policy Implications for Improving Public Attitudes and Facilitating Refugee Resettlement. Social Issues and Policy Review 11: 78-123. [CrossRef]

Fazel, Mina, Ruth V. Reed, Catherine Panter-Brick, and Alan Stein. 2012. Mental Health of Displaced and Refugee Children Resettled in High-Income Countries: Risk and Protective Factors. The Lancet 379: 266-82. [CrossRef]

Federle, Katherine H. 2017. Do Rights Still Flow Downhill? International Journal of Children's Rights 25: $272-84$. [CrossRef]

Ferguson, Lucinda. 2013. Not Merely Rights for Children but Children's Rights: The Theory Gap and the Assumption of the Importance of Children's Rights. International Journal of Children's Rights 21: 177-208. [CrossRef]

Freeman, Michael D. A. 2007. Why it Remains Important to Take Children's Rights Seriously. International Journal of Children's Rights 15: 5-23. [CrossRef]

Goodman, Simon, Ala Sirriyeh, and Simon McMahon. 2017. The Evolving (Re)categorisations of Refugees Throughout the "Refugee/Migrant Crisis". Journal of Applied Social Psychology 27: 105-14. [CrossRef] 
Goodnow, Jacqueline J., and Jeanette A. Lawrence. 2015. Children and Cultural Contexts. In Handbook of Child Psychology and Developmental Science, Vol. 4: Ecological Settings and Processes in Developmental Systems. Edited by Mark Bornstein and Tamara Leventhal. Hoboken: Wiley, pp. 746-88.

Gottlieb, Gilbert, and Carolyn T. Halpern. 2002. A Relational View of Causality in Normal and Abnormal Development. Development and Psychopathology 14: 421-35. [CrossRef] [PubMed]

Guyot, Julie. 2007. Child and Youth Participation in Protracted Refugee Situations. Children, Youth and Environments 17: 159-78.

Hanna, Andrew. 2019. A Constitutional Right to Appointed Counsel for the Children of America's Refugee Crisis. Harvard Civil Rights-Civil Liberties Law Review 54: 257-97.

Hanson, Karl, and Olga Nieuwenhuys. 2013. Living Rights, Social Justice, Translations. In Reconceptualizing Children's Rights in International Development: Living Rights, Social Justice, Translations. Edited by Karl Hanson and Olga Nieuwenhuys. Cambridge: Cambridge University Press, pp. 3-25.

Hanson, Karl. 2017. Embracing the Past: 'Been', 'Being' and 'Becoming' Children. Childhood 24: 281-85. [CrossRef]

Henderson, Claire. 2014. Australia's Treatment of Asylum Seekers: From Human Rights Violations to Crimes against Humanity. Journal of International Criminal Justice 12: 1161-81. [CrossRef]

Hodes, Matthew. 2010. The Mental Health of Detained Asylum-seeking Children. European Child and Adolescent Psychiatry 19: 621-23. [CrossRef]

Hopman, Marieke J. 2016. (Why) Should Children Have Rights?: A Philosophical Perspective. In The United Nations Convention on the Rights of the Child: Taking Stock after 25 Years and Looking Ahead. Edited by Tom Liefaard and Julia Sloth-Nielsen. Leiden: Brill/Nijhoff, pp. 272-93.

Hugo, Graeme. 2014. The Economic Contribution of Humanitarian Settlers in Australia. International Migration 52: 31-52. [CrossRef]

International Detention Coalition. 2010. Alternatives to Immigration Detention. Available online: https: //endchilddetention.org (accessed on 10 June 2019).

James, Allison. 2009. Agency. In The Palgrave Handbook of Childhood Studies. Edited by Jens Qvortrup, William A. Corsaro and Michael-Sebastian Honig. Basingstoke: Palgrave MacMillan Limited, pp. 34-45.

Kerwin, Donald. 2018. The US Refugee Resettlement Program-A Return to First Principles: How Refugees Help to Define, Strengthen, and Revitalize the United States. Journal of Migration and Human Security 6: 205-25. [CrossRef]

Kronick, Rachel, and Cécile Rousseau. 2015. Rights, Compassion and Invisible Children: A Critical Discourse Analysis of the Parliamentary Debates on the Mandatory Detention of Migrant Children in Canada. Journal of Refugee Studies 28: 544-69. [CrossRef]

Kronick, Rachel, Cécile Rousseau, and Janet Cleveland. 2018. Refugee children's sandplay narratives in immigration detention in Canada. European Child and Adolescent Psychiatry 27: 423-37. [CrossRef] [PubMed]

Kuczynski, Leon, and Jan De Mol. 2015. Dialectical Models of Socialization. In Handbook of Child Psychology and Developmental Science. Vol. 1: Theory and Method. Edited by Willis F. Overton and Peter C. M. Molenaar. Hoboken: Wiley, pp. 323-68.

Lawrence, Jeanette A., and Agnes E. Dodds. 2016. Developmental Science, Child Development and the Law. In Children and the Law in Australia, 2nd ed. Edited by Lisa Young, Mary Anne Kenny and Geoffrey Monaghan. Sydney: LexisNexus Butterworths, pp. 83-102.

Lawrence, Jeanette A., Ida Kaplan, and Agnes E. Dodds. 2015. The Rights of Refugee Children to Self-Expression and to Contribute to Knowledge in Research: Respect and Methods. Journal of Human Rights Practice 7: 411-29. [CrossRef]

Lawrence, Jeanette A., Ida Kaplan, and Amy H. Collard. 2016. Understanding the perspectives of refugee unaccompanied minors using a computer-assisted interview. Forum: Qualitative Social Research 17: 6. Available online: http://nbn-resolving.de/urn:nbn:de:0114-fqs160268 (accessed on 7 July 2019).

Lawrence, Jeanette A., Ida Kaplan, and Amy H. Collard. 2019a. Perspectives of Refugee Children Resettling in Australia on Indicators of Their Wellbeing. Child Indicators Research 12: 943-62. [CrossRef]

Lawrence, Jeanette A., Ida Kaplan, and Colleen McFarlane. 2013. The Role of Respect in Research Interactions with Refugee Children and Young People. In Values and Vulnerabilities: The Ethics of Research with Refugees and Asylum Seekers. Edited by Karen Block, Elisha Riggs and Nick Haslam. Bowen Hills: Australian Academic Press, pp. 103-26. 
Lawrence, Jeanette A., Shamiran Merkhaal, and Agnes E. Dodds. 2019b. Obstacles in the Pathway to Professional Life for a Chaldean Refugee Woman. Widening Participation and Lifelong Learning 21: 86-99. [CrossRef]

Liebel, Manfred. 2012. Children's Rights as Living Rights: Why Human Rights Only Make Sense if They are connected to the Lives of Children. Social Work Review 11: 13-26.

Linton, Julie M., Marsha Griffin, Alan J. Shapiro, and AAP Council on Community Pediatrics. 2017. Detention of Immigrant Children. Pediatrics 139: e20170483. Available online: aapublications.org/news (accessed on 7 July 2019).

Lucić, Luka. 2016. Developmental Affordances of War-torn Landscapes: Growing up in Sarajevo under Siege. Human Development 59: 81-106. [CrossRef]

Lundberg, Anna, and Jacob Lind. 2017. Technologies of Displacement and Children's Right to Asylum in Sweden. Human Rights Review 18: 189-208. [CrossRef]

Luster, Tom, Deborah J. Johnson, and Laura Bates. 2008. Lost boys Finding their Way: Challenges, Changes, and Small Victories of Young Sudanese Refugees in the United States. In Strengths and Challenges of New Immigrant Families. Edited by Rochelle L. Dalla, John De-Frain, Julie M. Johnson and Douglas A. Abbott. Lanham: Lexington Books, pp. 265-86.

McAdam, Jane. 2006. Seeking Asylum under The Convention of The Rights of the Child: A Case for Complementary Protection. International Journal of Children's Rights 14: 251-74. [CrossRef]

Montgomery, Edith. 2011. Trauma, Exile and Mental Health in Young Refugees. Acta Psychiatrica Scandanavia 124: 1-46. [CrossRef] [PubMed]

Morantz, Gillian, Cécile Rousseau, and Jody Heymann. 2011. The Divergent Experiences of Children and Adults in the Relocation Process: Perspectives of Child and Parent Refugee Claimants in Montreal. Journal of Refugee Studies 25: 71-92. [CrossRef]

Mousin, Craig B. 2019. Rights Disappear When US Policy Engages Children as Weapons of Deterrence. AMA Journal of Ethics 21: E58-E66. Available online: https://ssrn.com/abstract=3317913 (accessed on 3 July 2019).

Ní Raghallaigh, Muireann. 2013. The Causes of Mistrust Amongst Asylum Seekers and Refugees: Insights from Research with Unaccompanied Asylum-seeking Minors Living in the Republic of Ireland. Journal of Refugee Studies 27: 82-100. [CrossRef]

O'Higgins, Aoife. 2012. Vulnerability and Agency: Beyond an Irreconcilable Dichotomy for Social Service Providers Working with Young Refugees in UK. New Directions for Child and Adolescent Development 136: 79-91. [CrossRef] [PubMed]

Overton, Willis F. 2015. Processes, Relations, and Relational-developmental Systems. In Handbook of Child Psychology and Developmental Science. Vol. 1: Theory and Method. Edited by Willis F. Overton and Peter C. M. Molenaar. Hoboken: Wiley, pp. 9-62.

Parkin, C. Melanie, and Leon Kuczynski. 2012. Adolescent Perspectives on Rules and Resistance within the Parent-Child Relationship. Journal of Adolescent Research 27: 6323-658. [CrossRef]

Pobjoy, Jason M. 2017. The Child in International Refugee Law. Cambridge: Cambridge University Press.

Prout, Alan. 2011. Taking a Step Away from Modernity: Reconsidering the New Sociology of Childhood. Global Studies of Childhood 1: 4-14. [CrossRef]

Rania, N., Laura Migliorini, and Lucia Fagnini. 2018. Unaccompanied Migrant Minors: A Comparison of New Italian Interventions Models. Child and Youth Services Review 92: 98-104. [CrossRef]

Redden, Jack. 2013. A Million Children are Now Refugees from Syria Crisis. The UN Refugee Agency. Available online: http://www.unhrc.org/news/latest/2013/8/5216211999/million-children-refugees-syria-crisis-html (accessed on 4 August 2019).

Reynolds, Pamela, Olga Nieuwenhuys, and Karl Hanson. 2006. Refractions of Children's Rights in Development Practice. Childhood 13: 291-302. [CrossRef]

Shonkoff, Jack P., and Andrew S. Garner. 2012. The Lifelong Effects of Early Childhood Adversity and Toxic Stress. Technical Report Pediatrics 129: e232-46. [CrossRef] [PubMed]

Silverman, Stephanie J. 2016. "Imposter-Children" in the UK Refugee Status Determination Process. Refuge: Canada's Journal on Refugees 32: 30-39.

Silverman, Stephanie J., and Ben Lewis. 2017. Families in US Immigration Detention: What Does It Mean to do “The Right Thing"? Contemporary Readings in Law and Social Justice 9: 95-115. [CrossRef]

Slattery, Kate. 2003. Drowning not waving: The 'Children Overboard' Event and Australia's Fear of the Other. Media International Australia Incorporating Culture and Policy 109: 93-108. [CrossRef] 
Smyth, Ciara. 2019. Migration, Refugees, and Children's Rights. In International Human Rights of Children. Edited by Ursula Kilkelly and Ton Liefaard. Singapore: Springer Nature, pp. 421-54. [CrossRef]

Snodgrass Godoy, Angelina. 1999. 'Our Right is the Right to be Killed': Making Rights Real in the Streets of Guatemala City. Childhood 6: 423-42. [CrossRef]

Tisdall, E. Kay M. 2017. Conceptualising Children and Young People's Participation: Examining Vulnerability, Social Accountability and Co-Production. The International Journal of Human Rights 21: 59-75. [CrossRef]

Tyler, Tom R. 2006. Why People Obey the Law: Procedural Justice, Legitimacy, and Compliance. Princeton: Princeton University Press.

UN General Assembly. 1951. Convention Relating to the Status of Refugees. Treaty Series; New York: United Nations, Volume 189, p. 137. Available online: https://www.refworld.org/docid/3be01b964.html (accessed on 7 June 2019).

UN General Assembly. 1989. Convention on the Rights of the Child. Treaty Series; New York: United Nations, Volume 1577, p. 3. Available online: https://www.refworld.org/docid/3ae6b38f0.html (accessed on 28 April 2019).

UN High Commissioner for Refugees (UNHCR). 1994. Refugee Children: Guidelines on Protection and Care. Geneva: United Nations High Commission for Refugees, Available online: unhcr.org (accessed on 7 June 2019).

UN High Commissioner for Refugees (UNHCR). 2018. Global Compact on Refugees, Part II. Geneva: United Nations General Assembly Official Records, Seventy-Third Session, Supplement No. 12. Available online: unhcr.org (accessed on 7 June 2019).

Valibhoy, Madeleine C., Ida Kaplan, and Josef Swarc. 2017. "It Comes Down to Just How Human Someone Can Be": A Qualitative Study with Young People from Refugee Backgrounds about their Experiences of Australian Mental Health Services. Transcultural Psychiatry 54: 23-45. [CrossRef]

Valsiner, Jaan, and Jeanette A. Lawrence. 1997. Human Development in Culture across the Life Span. In Handbook of Cross-Cultural Psychology. Vol. 2. Basic Processes and Developmental Psychology, 2nd ed. Edited by John W. Berry, Pierre R. Dasen and T. S. Saraswathi. Boston: Allyn \& Bacon, pp. 69-106.

Valsiner, Jaan. 2014. An Invitation to Cultural Psychology. Los Angeles: Sage.

Veronese, Guido, Alessandro Pepe, Alaa Jaradah, Feda Murannak, and Housam Hamdouna. 2017. “We Must Cooperate with One Another Against the Enemy": Agency and Activism in School-Aged Children as Protective Factors Against Ongoing War Trauma and Political Violence in the Gaza Strip. Child Abuse and Neglect 70: 364-76. [CrossRef]

Victorian Foundation for the Survivors of Torture (VFST). 2019. Rebuilding Shattered Lives, 2nd ed. Brunswick: Victorian Foundation for the Survivors of Torture.

von Werthern, Martha, Katy Robjant, Zoe Chui, Rachel Schon, Livia Ottisova, Claire Mason, and Cornelius Katona. 2018. The Impact of Immigration Detention on Mental Health: A Systematic Review. BMC Psychiatry 18: 182-201. [CrossRef]

Wang, Qi, and Jessie B. Kim Koh. 2015. How will Things be the Next Time? Self in the Construction of Future Events among School-aged Children. Consciousness and Cognition 36: 131-38. [CrossRef] [PubMed]

Watters, Charles. 2012. Refugee and Displaced Children. Oxford: Oxford University Press.

Worster, William T. 2012. The Evolving Definition of the Refugee in Contemporary International Law. Berkeley Journal of International Law 30: 94-160. [CrossRef]

(C) 2019 by the authors. Licensee MDPI, Basel, Switzerland. This article is an open access article distributed under the terms and conditions of the Creative Commons Attribution (CC BY) license (http://creativecommons.org/licenses/by/4.0/). 